\title{
Mitigation of glyphosate side effects on non-target plants: use of different agrochemicals as protectants in common bean plants
}

\author{
Mitigação dos efeitos colaterais do glifosato em plantas não alvo: uso de \\ diferentes agroquímicos como protetores em feijoeiro
}

\author{
Chryz Melinski Serciloto' \\ Marcia Eugenia Amaral Carvalho \\ Paulo Roberto de Camargo e Castro ${ }^{3(*)}$
}

Abstract

Glyphosate is an herbicide widely used in agriculture. However, it may causes phytotoxic effects on non-target plants (crops), generating productivity losses. Currently there are evidences about agrochemicals as potential mitigators of glyphosate side effects. Therefore, the objective of this study was to evaluate the effects of distinct doses of fulvic acid 25\% (k-tionic 1000 and $2000 \mathrm{~mL} \mathrm{ha}^{-1}$ ), amino acids (Codamin $\mathrm{BR}^{\varpi} 500$ and $1000 \mathrm{~mL} \mathrm{ha}^{-1}$ ), phosphite (Nutex 0-30$20^{\oplus}, 2000$ and $4000 \mathrm{~mL} \mathrm{ha}^{-1}$ ) and biostimulant (Byozime $\mathrm{TF}^{\circledast} 250$ and $500 \mathrm{~mL}$ $\mathrm{ha}^{-1}$ ) in reversion of fitotoxicity caused by glyphosate on 'Carioca' common bean plants. For comparison, plants treated only with glyphosate, and untreated plants (control) were also evaluated. Glyphosate spray (Roundup WG $0.06 \mathrm{~kg} \mathrm{ha}^{-1}$ ) was performed at 31 days after planting (DAP), and agrochemicals were applied at 36 DAP. Phytotoxicity symptoms, as well as leaf area, dry mass of leaves and stems, and physiological indexes were evaluated at 54 DAP. Application of amino acid-based product $\left(500 \mathrm{~mL} \mathrm{ha}^{-1}\right)$ significantly reduced $(29.90 \%)$ phytotoxicity symptoms. Both doses of amino acid-based product increased dry mass of leaves; therefore, they were able to maintain the leaf weight ratio similar to the control plants. However, there was a decrease in leaf area, which was not reverted by any of the agrochemicals. It is concluded that application of amino acid-based product

I Dra.; Engenheira Agrônoma; Funcionária da Isagro Brasil Comercio de Produtos Agroquímicos Ltda; Endereço: Rua Joaquim Floriano, 466 / Cj I205, Itaim Bibi, CEP: 04534-002, São Paulo, São Paulo, Brasil; E-mail: chryz.serciloto@fmc.com

2 MSc.; Bióloga; Doutoranda em Genética e Melhoramento de Plantas na Escola Superior de Agricultura "Luiz de Queiroz" ESALQ/USP; Endereço: Avenida Pádua Dias, II, São Judas, CEP: I34I8-900, Piracicaba, São Paulo, Brasil; E-mail: marcial988I I@usp.br

3 Dr.; Engenheiro Agrônomo; Professor Titular da Universidade de São Paulo, USP; Endereço:Avenida Pádua Dias, I I, Agronomia, Caixa Postal: 09, CEP: I34 I8-900, Piracicaba, São Paulo, Brasil; E-mail: prcastro@usp.br (*) Autor para correspondência.

Recebido para publicação em 04/04/2012 e aceito em 02/06/2014

Ambiência Guarapuava (PR) v.10 n.2 p. 6I5 - 623 Maio/Ago. 2014 ISSN I808 - 025 I DOI: 10.5935/ambiencia.2014.02.13nt 
(Codamin BR $500 \mathrm{~mL} \mathrm{ha}^{-1}$ ) reduces, even partially, glyphosate phytotoxicity in 'Carioca' common bean plants.

Key words: amino acids; glyphosate non-resistant crop; Phaseolus vulgaris; phytotoxicity reversion; Roundup.

\section{Resumo}

Glifosato é um herbicida amplamente usado na agricultura. Entretanto, ele pode causar efeitos fitotóxicos em plantas não alvo (culturas), gerando perdas de produtividade. Atualmente existem evidências sobre alguns agroquímicos como potenciais mitigadores dos efeitos colaterais do glifosato. Deste modo, o objetivo deste estudo foi avaliar a influência de diferentes doses de ácido fúlvico $25 \%$ (k-tionic ${ }^{\circledast} 1000$ e $2000 \mathrm{~mL} \mathrm{ha}^{-1}$ ), aminoácidos (Codamin BR 500 e $1000 \mathrm{~mL}$ $\mathrm{ha}^{-1}$ ), fosfito (Nutex 0-30-20 2000 e $4000 \mathrm{~mL} \mathrm{ha}^{-1}$ ) e bioestimulante (Byozime $\mathrm{TF}^{\circledast} 250$ e $500 \mathrm{~mL} \mathrm{ha}^{-1}$ ) na reversão de fitotoxicidade causada por glifosato em feijoeiros 'Carioca'. Para comparação, também foram avaliadas plantas tratadas apenas com glifosato e plantas não tratadas (controle). A pulverização de glifosato (Roundup WG 0,06 $\mathrm{kg} \mathrm{ha}^{-1}$ ) foi realizada 31 dias após o plantio (DAP) e os agroquímicos foram aplicados aos 36 DAP. Os sintomas de fitotoxicidade, bem como a área foliar, massa seca de folhas e caules e índices fisiológicos foram avaliados 54 DAP. Aplicação de produto à base de aminoácidos $\left(500 \mathrm{~mL} \mathrm{ha}^{-1}\right)$ reduziu significativamente $(29,90 \%)$ de sintomas de fitotoxicidade. Ambas as doses do produto à base de aminoácidos aumentaram da massa seca de folhas e, deste modo, mantiveram a razão de peso foliar semelhante à das plantas controle. No entanto, houve diminuição da área da folha, que não foi revertida por nenhum dos agroquímicos utilizados. Conclui-se que a aplicação do produto à base de aminoácidos (Codamin BR $500 \mathrm{~mL} \mathrm{ha}^{-1}$ ) reduz parcialmente a fitotoxicidade do glifosato em plantas de feijão 'Carioca'.

Palavras-chave: amino ácidos; culturas não resistentes ao glifosato; Phaseolus vulgaris; reversão de fitotoxicidade; Roundup.

\section{Introduction}

Tillage system is used in approximately 25 million hectares, representing $50 \%$ of the area with annual crops in Brazil. The adoption of this practice was possible due to development of herbicides, among which glyphosate is the most used (YAMADA et al., 2009). This herbicide affects shikimic acid pathway by inhibiting the synthesis of 5-enolpyruvoylshikimate-3-phosphate synthase, thus preventing the synthesis of three essential amino acids - tryptophan, phenylalanine and tyrosine (RODRIGUES et al., 1982).

The fast translocation of glyphosate from treated leaves to roots, rhizomes 
and apical meristems, is one of its most important features. The in vivo stability of glyphosate also contributes to its irreversible phytotoxic effects (GRUYS; SIKORSKI, 1999). In addition of drift and residual glyphosate in soil, this herbicide may be transferred from target (weed) to non-target plants (crop), through contact among roots (RODRIGUES et al., 1982). Leaf chlorosis followed by necrosis are the common symptoms due to glyphosate application. Other symptoms in leaves are wrinkling or malformations (especially in growth areas) and necrosis of meristem, rhizomes and stolons of perennial plants (GRUYS; SIKORSKI, 1999).

However, several compounds are potential mitigators of glyphosate phytotoxic effects on non-target plants. The application of sucrose $2 \%$ on coffee plants, a week after glyphosate pulverization, reversed phytotoxicity caused by this herbicide (MARTIN, 2003). The use of amino acid-based products as seed treatment and/or foliar sprays also reduced symptoms of phytotoxicity in glyphosateresistant soybean (ZOBIOLE et al.,2010). Therefore, the objective of this study was to evaluate the effects of some agrochemicals as mitigators of glyphosate phytotoxicity in 'Carioca' common bean plants.

\section{Materials and Methods}

The experiment was carried out in a greenhouse without humidity and temperature control, at Piracicaba in southeastern of Brazil (latitude 22 ${ }^{\circ} 42^{\prime}$ $\mathrm{S}$, longitude 47o 38' W), from September to November. Common bean (Phaseolus vulgaris cv. Carioca) seeds were sown in $8 \mathrm{dm}^{3}$ plastic pots filled with clay, sand and manure in the ratio of $2: 2: 1(\mathrm{v}: \mathrm{v}: \mathrm{v})$, respectively; and three plants remained in each pot.

\section{Treatments}

The treatments were 1- control, 2glyphosate, 3- glyphosate + fulvic acid 25\% (k-tionic $\left.1000 \mathrm{~mL} \mathrm{ha}^{-1}\right)$, 4- glyphosate + fulvic acid 25\% (k-tionic $2000 \mathrm{~mL} \mathrm{ha}^{-1}$ ), 5- glyphosate + amino acids (Codamin BR $\left.500 \mathrm{~mL} \mathrm{ha}^{-1}\right), 6$ - glyphosate + amino acids (Codamin BR $1000 \mathrm{~mL} \mathrm{ha}^{-1}$ ), 7- glyphosate + phosphite (Nutex 0-30-20, $2000 \mathrm{~mL}$ $\mathrm{ha}^{-1}$ ), 8- glyphosate + phosphite (Nutex 0-30-20, $\left.4000 \mathrm{~mL} \mathrm{ha}{ }^{-1}\right)$, 9- glyphosate + biostimulant (Biozyme TF $250 \mathrm{~mL}$ $\mathrm{ha}^{-1}$ ), and 10- glyphosate + biostimulant (Biozyme TF $500 \mathrm{~mL} \mathrm{ha}^{-1}$ ). Glyphosate (Roundup WG $0.06 \mathrm{~kg} \mathrm{ha}^{-1}$ ) was applied in third trifoliate stage (31 days after planting - DAP), and the application of agrochemicals was performed at 36 DAP.

Phytotoxicity was evaluated by three reviewers, who gave scores to symptomatology caused by glyphosate at 36, 40, 46 and 54 DAP. These scores were according to the scale of visual assessment of herbicides phytotoxicity proposed by European Weed Research Council (EWRC, 1964), ranging from 1 (no symptoms) to 9 (plant death). At 54 DAP, leaf area was determined through Area Meter Li-Cor 2000 equipment. Subsequently, leaves and stems were placed in an oven at $65 \pm 2{ }^{\circ} \mathrm{C}$ for 4 days, to obtain the dry mass of leaves (DML), stems (DMS), and shoots (DMS = DML+DMS). The leaf weight ratio $(\mathrm{LWR}=\mathrm{DML} /$ 
DMS $)$, leaf area ratio $(\mathrm{LAR}=\mathrm{LA} / \mathrm{DMS})$ and specific leaf area $(\mathrm{SLA}=\mathrm{AF} / \mathrm{DML})$ were also calculated.

The experiment was carried out in a completely randomized design with 10 treatments and 6 replications with three plants each. Data were subjected to analysis of variance (ANOVA) at 5\% of significance level. Subsequently, Duncan's test $(\alpha \leq 0.05)$ was used to compare means among treatments. All procedures were performed through $\mathrm{SAS}^{\oplus}$ statistical program (SAS, 2011).

\section{Results and Discussion}

$\mathrm{K}$-tionic ${ }^{\oplus}$ is composed by fulvic acids (25\%), the most biologically active fraction of humic substances due to low molecular weight and solubilization at any $\mathrm{pH}$ (SCHMIDT et al., 2003). Fulvic acids containing polysaccharides, amino acids and auxins that can provide plant development (FAÇANHA et al., 2002; SCHMIDT et al., 2003). Codamin BR ${ }^{\circ}$ is an amino acid-based product $(100 \mathrm{~g}$ $\left.\mathrm{L}^{-1}\right)$, which also contains $\mathrm{N}\left(7.3 \mathrm{~g} \mathrm{~L}^{-1}\right)$, Fe (1\%), Mn (0.6\%) and $\mathrm{Zn}(0.4 \%)$. It can increase the nutrient content of plants, as well as biomass allocated in leaves, stems and seeds (CASTRO et al., 2006, 2008).

Nutex $00-20-30^{\circ}$ is composed by phosphite (2-3 $\left.\mathrm{mL} \mathrm{L}^{-1}\right), \mathrm{P}\left(\mathrm{P}_{2} \mathrm{O}_{5} 30 \%\right)$ and $\mathrm{K}\left(\mathrm{K}_{2} \mathrm{O} 20 \%\right)$. Phosphite $\left(\mathrm{H}_{2} \mathrm{PO}_{3}^{-}\right)$has been used in agriculture to increase crop productivity and quality. It is considered a phosphorus source, and possibly acts as signal activator, triggering plant responses that include metabolism changes of endogenous hormones (CASTRO et al., 2008). Biozyme $\mathrm{TF}^{\infty}$ is a biostimulant compound by hydrolyzed plant extracts, plant growth regulators [giberellins $(32.2 \mathrm{ppm})$, indoleacetic acid (32.2 ppm), zeatin (83.2 $\mathrm{ppm})]$ and micronutrients $[\mathrm{Mn}(0.12 \%), \mathrm{Zn}$ (0.37\%), $\mathrm{Fe}(0.49 \%), \mathrm{Mg}(0.14 \%), \mathrm{B}(0.30 \%)$ and S (0.44\%)]. According to Tavares and Castro (2002), it is able to provide the genetic potential of crops.

All plants treated with glyphosate showed phytotoxicity symptoms, but the use of agrochemicals partially mitigated them. This reversion tended to be less pronounced with time, which indicates that other applications may be a suitable strategy to alleviate these symptoms (Figure 1).

Amino acid-based product (both doses) was the more efficient mitigator because it provided a high reduction of phytotoxicity symptoms, and also maintained the reversion during a time more long than the other agrochemicals. Probably these results were due to amino acids replaced by product, since glyphosate's negative effects are mainly due to interruption of aromatic amino acids synthesis (RODRIGUES et al., 1982)

The dry mass of stems was not affected by herbicide (figure 2), but there was a decrease in dry mass of leaves (Figure 2). Only amino acidbased product was able to mitigated this effect, indicating again that exogenous application of amino acids can reverts the side effects of glyphosate on nontarget plants. 
Figure 1 - Phytotoxicity level in bean plants (Phaseolus vulgaris cv. Carioca) treated with distinct agrochemicals (doses ranging from 250 to $4000 \mathrm{~mL} \mathrm{ha}^{-1}$ ) at 5, 9, 15 and 23 days after glyphosate application
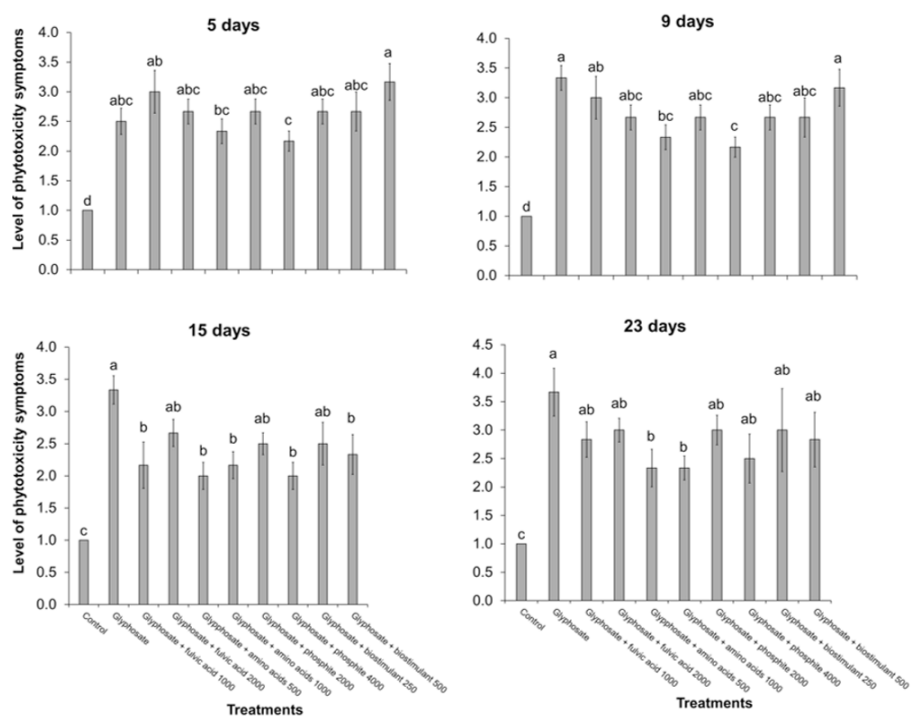

Source:Authors (20/2).

Note: Means \pm standard error. Means followed by distinct letters differ by Duncan's test $(\alpha \leq 5 \%)$.

Figure 2 - Dry mass of stems and leaves of bean plants (Phaseolus vulgaris cv. Carioca) treated with distinct agrochemicals (doses ranging from 250 to $4000 \mathrm{~mL}$ ha-1) after glyphosate application
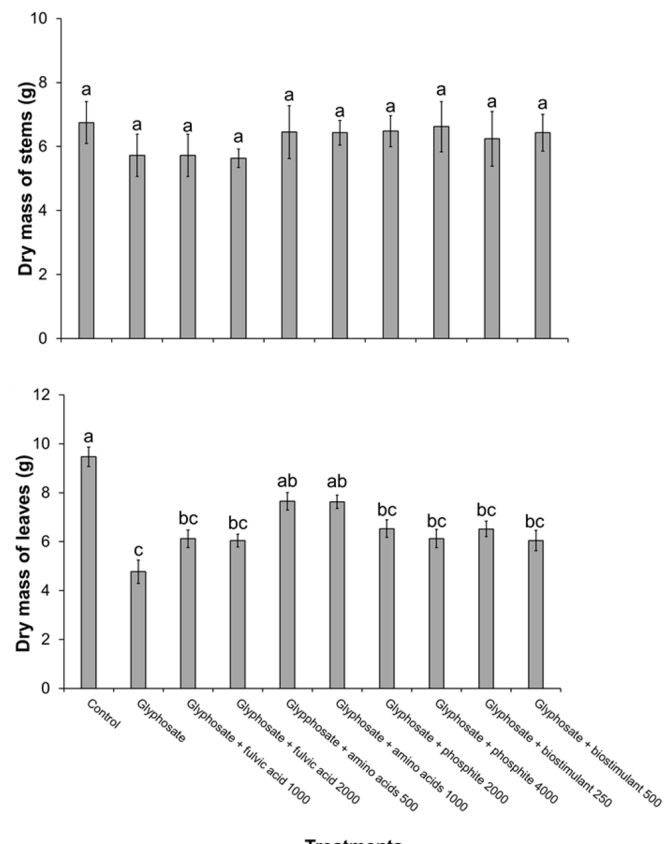

Source:Authors (2012).

Treatments

Note: Means \pm standard error. Means followed by distinct letters differ by Duncan's test $(\alpha \leq 5 \%)$. 
The decrease of leaf biomass was responsible by reduction of shoot dry mass and leaf weight ratio, as shown in figure 3. These effects probably were due to deregulation of shikimic acid pathway, which results in loss of carbon available (approximately 20\%) for other reactions, since tyrosine, phenylalanine and tryptophan are precursors of the most of aromatic compounds in plant (FERREIRA et al., 2005).

Figure 3 - Dry mass of shoots and leaf weight ratio of bean plants (Phaseolus vulgaris cv. Carioca) treated with distinct agrochemicals (doses ranging from 250 to $4000 \mathrm{~mL}$ $\left.\mathrm{ha}^{-1}\right)$ after glyphosate application
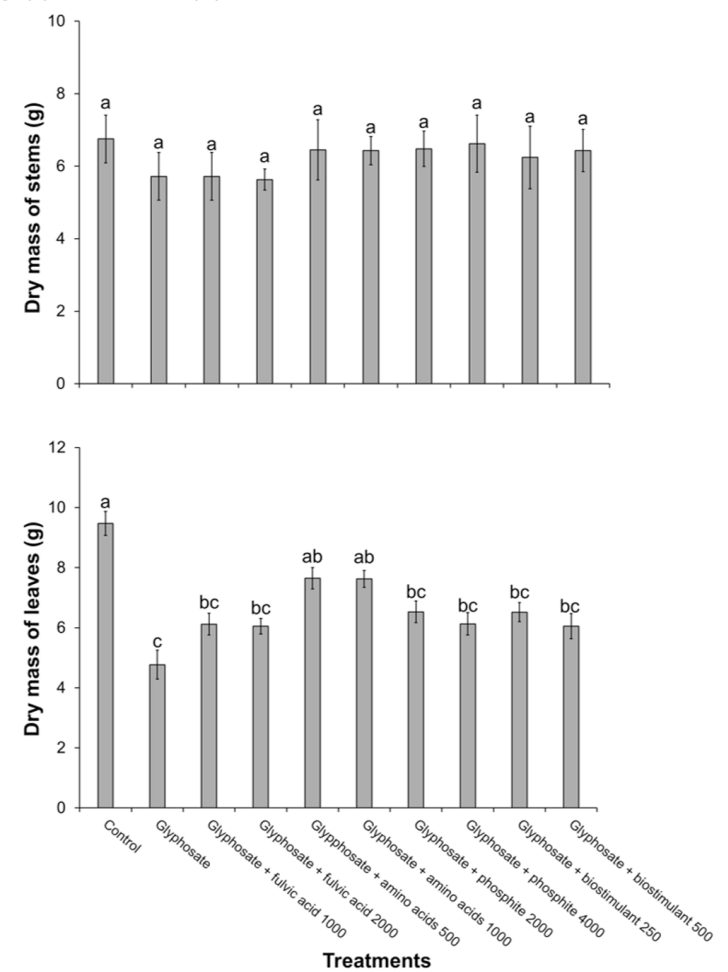

Source:Authors (2012).

Note: Means \pm standard error. Means followed by distinct letters differ by Duncan's test ( $\alpha \leq 5 \%)$.

The loss of biomass also can be related to increase of stomatal resistance, reduction of chlorophyll content and decrease of photosynthetic activity in leaves, which impairs the production of photosynthates (BRECKE; DUKE, 1980; TAIZ; ZEIGER, 2010; ZOBIOLE et al., 2010; CARVALHO et al., 2013). This herbicide also restricts nutrient absorption (CAKMAK et al., 2009), so there are a probability that mitigation of side effects can be due, even partially, to replacement of nutrients found in amino acid-based product, since some nutrients take part in stomatal aperture, chlorophyll molecules, and photosynthetic mechanisms (TAIZ; ZEIGER, 2010). However, all glyphosatetreated plants showed a decrease in leaf area, which was not reverted by any of the used agrochemicals (Figure 4). 
Figure 4 - Leaf area, leaf area ratio and specific leaf area of bean plants (Phaseolus vulgaris cv. Carioca) treated with distinct agrochemicals (doses ranging from 250 to 4000 $\mathrm{mL} \mathrm{ha}{ }^{-1}$ ) after glyphosate application
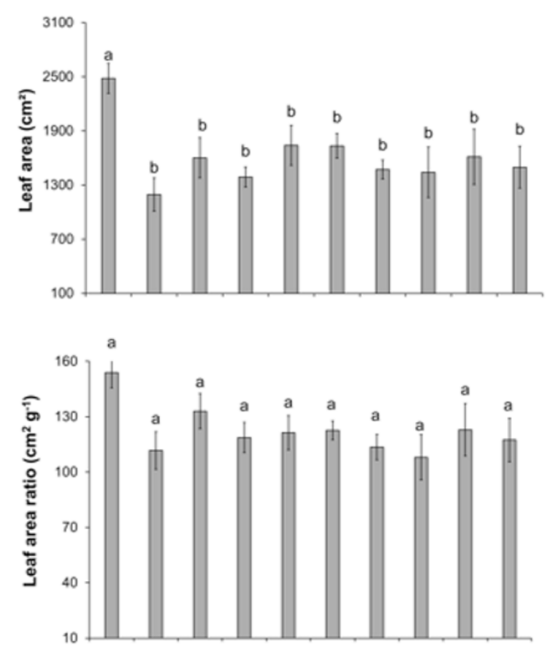

Source:Authors (2012).

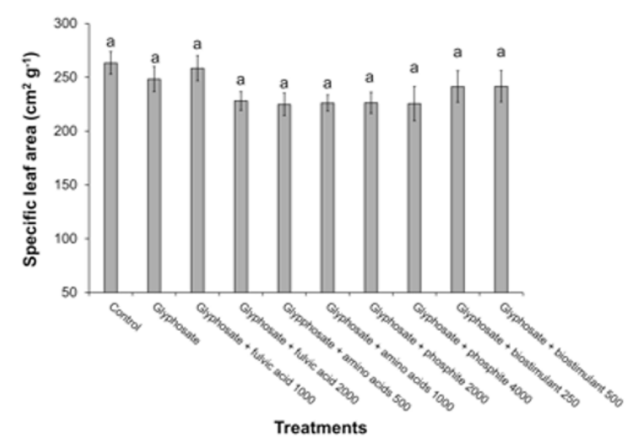

Note: Means \pm standard error. Means followed by distinct letters differ by Duncan's test $(\alpha \leq 5 \%)$.

In fact, inhibition of leaf expansion of bean plants can start after 25 hours of glyphosate application, as demonstrated by Brecke and Duke (1980). Leaf area of coffee plants was also reduced (CARVALHO et al., 2013), and flag leaves of rice plants showed slow and stunted growth, emerging as a shortened organ (DAVIS et al., 2011). Taken together, these results indicate that reduction of leaf area is a fast and common effect caused by glyphosate.

However, leaf area ratio and specific leaf area did not varied among treatments (figure 4), this results was due to a proportional reduction in leaf area and dry mass of leaves, which provide a similar value when theses physiological indexes were calculated.

\section{Conclusion}

It can be conclude that the amino acidbased product used in this study (Codamin BR $500 \mathrm{~mL} \mathrm{ha}^{-1}$ ) acts as protectant against the side effects of glyphosate in 'Carioca' common bean plants, because it alleviated the phytotoxic symptoms and maintained 
the regular biomass partition of plants treated with this herbicide. However, this agrochemical is not able to revert the leaf area reduction caused by glyphosate, therefore it can be state that the side effects of glyphosate in 'Carioca' common bean plants can be partially mitigate by Codamin BR $500 \mathrm{~mL}$ $\mathrm{ha}^{-1}$. Furthermore, the doses of the other agrochemicals tested did not are efficient in the reversion of negative effects of glyphosate on 'Carioca' bean plants.

\section{Support}

Coordenação de Aperfeiçoamento de Pessoal de Nível Superior (CAPES).

\section{References}

BRECKE, B.J.; DUKE, W.D. Effect of glyphosate on intact bean plants (Phaseolus vulgaris L.) and isolated cells. Plant Physiology, Rockville, v. 66, p. 656-659, 1980.

CAKMAK, I.; YAZICI, A.; TUTUS, Y.; OZTURK, L. Glyphosate reduced seed and leaf concentrations of calcium, manganese, magnesium and iron in non-glyphosate resistant soybean. European Journal of Agronomy, Amsterdam, v. 31, n. 3, p. 114-119, 2009.

CARVALHO, F. P.; FRANÇA, A. C.; LEMOS, V. T.; FERREIRA, E. A.; SANTOS, J. B.; SILVA, A. B. Photosynthetic activity of coffee after application of glyphosate subdoses. Acta Scientiarum. Agronomy, Maringá, v. 35, n. 1, p. 109-115, 2013.

CASTRO, P. R. C.; GONÇALVES, M. R.; CATO, S. C. Efeitos da aplicação foliar de Codamin e de Brassinolide em feijoeiro. Revista de Agricultura, Piracicaba, v. 81, n.1, p. 24-30, 2006.

CASTRO, P. R. C.; SERCILOTO, C. M.; PEREIRA, M. A.; RODRIGUES, J. L. M. Utilização de fosfitos e potencial de aplicação dos aminoácidos na agricultura tropical. Piracicaba: ESALQ/DIBD, 2008. (Série Produtor Rural, 38).

DAVIS, B.; SCOTT, R. C.; NORSWORTHY, J. K.; GBUR, E. Response of rice (Oryza sativa) to low rates of glyphosate and glufosinate. Weed Technology, Lawrence, v. 25, n. 2, p. 198-203, 2011.

EWRC. European Weed Research Council. Report of the third and fourth meetings of the European Weed Research Council Committee of Methods. Weed Research, Lawrence, v. 4, p. 88, 1964.

FAÇANHA, A. R.; FAÇANHA, A. L. O.; OLIVARES, F. L.; GURIDI, F.; SANTOS, G. A.; VELLOSO, A. C. X.; RUMJANEK, V. M.; SCHRIPSEMA, J.; BRAZ-FILHO, R.; OLIVEIRA, M. A.; CANELLAS, L. P. Bioatividade de ácidos húmicos: efeitos sobre o desenvolvimento radicular e sobre a bomba de prótons da membrana plasmática. Pesquisa Agropecuária Brasileira, Brasília, v. 37, n. 9, p. 1301-1310, 2012.

FERREIRA, F. A.; SILVA, A. A.; FERREIRA, L. R. Mecanismos de ação de herbicidas In: CONGRESSO BRASILEIRO DE ALGODÃO, 5., 2005, Salvador. Anais... Campina Grande: Embrapa Algodão, 2005. 1 CD-ROM. 
GRUYS, K. J.; SIKORSKI, J. A. Inhibitors of tryptophan, phenylalanine and tyrosine biosynthesis as herbicides. In: SINGH, B. K. (Ed.). Plant amino acids: biochemistry and biotechnology. New York: Marcel Dekker, 1999. p. 357-384.

MARTIM, S. A. Pulverização do cafeeiro com açúcar: potencial de uso em mudas submetidas à deficiência hídrica e na recuperação de plantas atingidas pelo glifosato. 2003. 67 f. Dissertação (Mestrado em Agronomia) - Universidade Federal de Lavras, UFLA, Lavras, 2003.

RODRIGUES, J. J. V.; WORSHAM, A. D.; CORBIN, F.T. Exudation of glyphosate from wheat (Triticum aestioum) plants and its effects on intraplanting with corn (Zea mays) and soybeans (Glycine max). Weed Science, Lawrence, v.30, p.316-320, 1982.

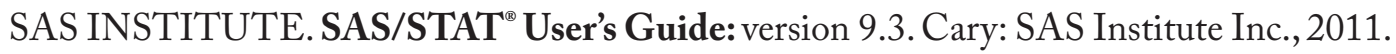

SCHMIDT, R. E.; ERVIN, E.H.; ZHANG,X.Questions and answers about biostimulants. Golf Course Management, Lawrence, v.71, n.6, p.91-94, 2003.

TAIZ, L.; ZEIGER, E. Plant physiology. $5^{\text {th }}$ ed. Massachusetts: Sinauer Associates, 2010.

TAVARES, S.; CASTRO, P. R. C. Avaliação do efeito de Biozyme TF na produtividade da batata 'Bintje'. Revista Cultivar, Pelotas, v.3, n.14, p. 4, 2002.

YAMADA,T.; KREMER, R.J.; CASTRO, P. R. C.; WOOD, B.W. Glyphosate interactions with physiology, nutrition and diseases of plants: threat to agricultural sustainability? European Journal of Agronomy, Amsterdam, v.31, n.3, p.111-113, 2009.

ZOBIOLE, L. H. S.; OLIVEIRA JUNIOR., R. S.; CONSTANTIN, J.; BIFFE, D. F. Prevenção de injúrias causadas por glyphosate em soja $\mathrm{RR}$ por meio do uso de aminoácidos. Planta Daninha, Viçosa, v.29, n.1, p.195-205, 2010. 